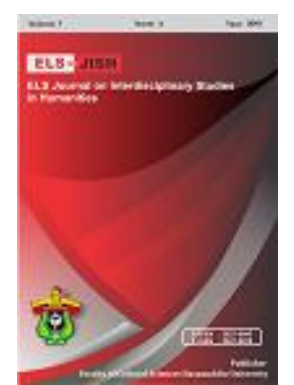

ELS-JISH

ELS Journal on Interdisciplinary Studies on Humanities

Volume 2 Issue 4, 2019

ISSN (print) : 2621-0843

ISSN (online) : 2621-0835

Homepage : http://journal.unhas.ac.id/index.php/jish

\title{
Students' Perceptions on Reflective Journal as Self-Assessment to promote writing skills in EFL Class
}

\author{
Hanna Novariana Azizah Ni'ma ${ }^{1}$, Sumardi ${ }^{2}$, Sri Samiati Tarjana ${ }^{3}$ \\ ${ }^{1}$ hana.novariana16@gmail.com
}

\begin{abstract}
The purpose of this study was to examine students' perspective on best practices to promote writing skill by using self-assessment technique named reflective journal in EFL class. The method of this study is qualitative research. The data collected and analyzed from this study to compromise a better understanding of students' perspective on how reflective journal writing of self-assessment promotes their writing proficiency. In this study, the writer collected the data by using semi-structured interviews and focused on twelve students from high school who taught by using reflective journal in Surakarta, Jawa Tengah. The finding of this study identified how students' perspectives on reflective journal to promote their writing proficiency. The result of this study indicated the positive impacts of reflective journal in enhancing students' writing proficiency. Nevertheless, there were several difficulties students faced during learning process. There were also some challenges such as students' lack of motivation. However, both the teacher and the students were actively involved in overcoming those problems. In sum, students thought that reflective journal makes their writing practices exciting, enjoying, and motivating.
\end{abstract}

Keywords: Students' Perception, Reflective Journal, Self-Assessment, Teaching Writing

How to cite: Ni'ma, H., et. al. (2019). Students' Perceptions on Reflective Journal as Self-Assessment to promote writing skills in EFL Class. ELS Journal on Interdisciplinary Studies in Humanities, 2(4), 626-632

\section{Introduction}

Generally, writing is scientific work in the field of EFL learning, students in Indonesia should be able to perform a good writing in order to complete their study. It has been widely known that nowadays writing is a foreign language that important not only as an object of study but also as a system of communication. Writing is one of important skills in English that students can explore and share ideas, knowledge, and experiences as well as express their feeling and thinking. Accordingly, students should give optimal efforts in helping them mastering writing because it is considered as the most difficult skill in English (Hughey, et al. 1983; Murcia, et al. 2000).

In writing, self-assessment enables learners to monitor their progress in learning to write and set their own learning goals. In other words, it encourages the learners the reflection needed to gain increased control as writers (O'Malley and Pierce, 1996). Self-assessment is a process through which students must be led

\footnotetext{
${ }^{1,2,3}$ Sebelas Maret University, Indonesia 
(O'Malley and Pierce, 1996). Teaching students to evaluate their progress begins with realizing that students will be learning new skills and it can be carried out with these four steps: setting criteria, applying criteria, setting and working towards goals.

Reflection is defined by Moon, one of the most well-known advocates of the use of reflective learning journals in this country, as "a form of mental processing with a purpose and/or anticipated outcome that is applied to relatively complex or unstructured ideas for which there is not an obvious solution." (1999). According to Moon, one of the prerequisites of reflection is that it should serve a purpose and have an anticipated outcome. It is used to help students to "(1) consider the process of (one's) own learning (metacognition), (2) critically review (their learning materials),(3) build theories from observation and finally (4) engage in personal or selfdevelopment; or to empower themselves as individual (learners)." (ibid: 23-24) Each of these purposes is incorporated into our series of prompt questions for students to write their reflective learning journals in the present project (See appendix A for more details)

So that, Reflective learning journals are widely used in practice- or work-based disciplines and/or professional education, e.g. nursing, teacher training, etc. The rationale behind this is that students learn from reflecting critically upon their experiences or practices. The theoretical background originates in Kolb's (1985) famous 'experiential learning cycle' which involves 'concrete experiences', 'reflective observation', 'abstract conceptualisation', and finally 'active experimentation'. In other words, professionals learn through the cycle of 'doing' and 'reflecting', 'forming principles', 'planning' and finally going back to 'doing' (Kelly, 2005). In fact, learning from experience is seen by many educators as a crucial way of narrowing the gap between theory and practice in their respective disciplines (Bulpitt \& Martin, 2005).

As a one of self-assessment method, Reflective journal is a tool to observes in students' recent issue and to foster their self-awareness necessary to facilitate learning transfer, others have expressed concerns about the quality of their reflective writing but also about the complicated power dynamics involved when self-reflective writing is assigned in a class, by a teacher (Sommers, 2011). As instructors, teachers think more critically about students in these texts and to acknowledge the possibility those students may write "what they think we want to hear" (Smith and Yancey, 2000). The most common response to these concerns about reflective writing is that what is needed is more consistent support and guidance to promote better student reflection. As Bowers (2003) writes, "Because metacognition is a complex skill, reflection should be integrated into the classroom from beginning to end, progressing from simple to more complex reflective problem-solving questions". Smith and Yancey (2000) urge instructors to be more precise in communicating what we mean by "good" reflection and how it differs from "inadequate" reflection, while Conway (1994) insists that "required reflection is ethical only if it exists as an ongoing component of a course and if the teacher of that course openly discusses his or her reactions to the reflections with students".

In the term of perception, Nanay (2013) says that perception deals with an action. That refers to the process of recognizing and understanding events, objects, and stimuli through the use of sense such as sight, hearing, and touch (Richards \& Schmidt, 2010). Borg (2003, p. 81) states that perceptions concern with what individuals knowledge, beliefs, and thought. Woods (1996) as cited in (Golombek, 
2009) also asserts that perception relates to three things including belief, attitude, and knowledge. Belief deals with the concept in a mind that it is narrower than knowledge and it influences attitude (Skott, 2015). Attitude deals with preference about specific phenomenon (Schraw \& Olafson, 2015). Meanwhile, knowledge deals with a concept. In short, it can be said that perception deals with someone's belief, attitude, and knowledge about a particular case.

In this research, our high school students' curriculum is organized into three strands: theory, practice and language in each academic year. Since a year ago, the researcher decided to introduce reflective learning journals as a part of the assessment scheme in replacement of essay-style coursework while keeping the end-of-the-semester summative examination intact. This is partly to support the required self-assessment elements of students' reflective journal. But, more importantly, it is designed to engage high school students in writing class. Students were asked to submit four journal entries at two stages and each journal entry should be 200 words minimum in length. Students' consent was acquired at the end of the semester after their journal submission. They were told that their work may be quoted anonymously in a publication drafted by the researcher. A preliminary analysis of students' journal entries showed that a reflective learning journal has the potential of engaging and enhancing students' writing skills, since the evidence suggests that students take on the initiative of independent learning and relating theories to their practice. One other important finding was that journal writing seems to, if unintentionally, provide a platform for 'synoptic learning' (Gorra et al: 2008), where students make connections between modules and consolidate their writing skills as a whole.

Considering the previous researches above, this research tried to investigate students' perception about reflective journal as self-assessment in writing class at one of High school in Indonesia. This research focuses on reflective journal as selfassessment in writing class. The findings that will be obtained from this study may contribute to the related literature through seeking answers to the following research questions:

1. What are students' perceptions of reflective journal as self-assessment in writing class?

2. What are problems faced by students when they teach using reflective journal as self-assessment in EFL writing class?

3. What are suggestions proposed by students when they teach using reflective journal as self-assessment in EFL writing class?

\section{Research Methodology}

This is a qualitative study that explores students' perception of reflective journal as self-assessment in EFL Writing Class. The participants chosen based on the purpose of this study were High schools students in Indonesia. The purpose of choosing the case was to excavate deeper tools for understanding of a phenomenon (Gall, Meredith, Gall, Joyce, \& Borg, Walter, 2003). The research data were collected from twelve students through the use of semi-structured interviews that cover questions about participants' knowledge, beliefs, and attitudes. The data obtained 
from the interviews were the interviewee's statements in response to the questions. The interview protocol was developed based on Patton (1991).

The collected data was analyzed and interpreted qualitatively. The researcher analyzed the data adapted from Ary, Jacobs, Lucy, Sorensen, \& Razavieh (2010). Qualitative analysis involves three stages of organizing and familiarizing, coding and reducing, and interpreting and representing. All qualitative analysis involves attempts to comprehend the phenomenon under study, synthesizes information and explains relationships, theorizes how and why the relationships appear as they do, and reconnects the new knowledge with what is already known.

\section{Research Results}

This study provided personal information related to the participants' experiences in using reflective journal including duration and students' writing skill in using reflective journal, whether or not they benefit their writing skills, and the availability of reflective journal. Those are very important to serve a wide picture of the participants' background in using reflective journal. To give a clear explanation, the researcher presents result of the study as well as discusses their implication.

\subsection{Students' Perception of the concept of reflective journal}

The students' knowledge about reflective journal as self-assessment in writing for high school students is identified in her statements during the interview. A large number of students describe that reflective journal is method to help them to assess their English skill and help them to practice their writing through daily reflective journal, although a half of the students seem to find writing reflective learning journals difficult; the other half seems find it not particularly difficult. In fact, one student even mentioned that she enjoys writing journals. For those students who indicated difficulty in writing journals, most of them mentioned that this was because they have not written reflective learning journals before and they were not sure what or how to write.

In terms of whether students feel that their view of learning has been changed by writing reflective journals, there are no conclusive results. Some of them indicate that they now know that learning is not for teachers but for one's personal benefits, while others are not so sure that it really challenges their view of learning since they already know that one has to learn by reading, as indicated by one student.

\subsection{Advantages of reflective journal in EFL class}

One of the aims of the present research project is to find out the potential of reflective learning journals to promote writing skill from students' points of view. The majority of students confirm that reflective learning journals help them to learn their skills and help them to practice their writing. It was indicated that this is because in order to write they have to revise what they learned and read. Again, this is probably due to the very nature of journal writing where relative freedom are given to students in terms of choosing what to write and what to reflect upon related to their English learning achievements. This relative freedom, a new found one for most students, poses some apparent difficulty, as mentioned before. Yet, at the same time, this very freedom of not imposing specific theories on students forces them to scrutinize what they have learned and decide what they want to read more about so that they can write reflective journals. By doing that, students are actually empowered to take on 
more responsibility for their own learning and encouraged to become more independent learners. However, they glad that all their actions are under teacher guidelines and helps so that they able to overcome some of their difficulties in writing reflective journal.

On the other hand, Most of them describe English language learning as a subject that can help them prepare themselves to be ready to work in certain fields. They state that learning English is very valuable for them because during the learning process they could cultivate their English skills by practicing their writing. In relation with the source of knowledge, the students know the information about reflective journal as self-assessment from various sources such as their teacher, books, and the internet but they mostly agree that information is obtained from the teacher.

It can be concluded that the students' contentedness about reflective journals as it improves five indicators of writing including content, organization, grammar, vocabulary, and mechanics. It also gave contribution in motivating students (useful and interesting), enhancing communication between teacher and students, improving knowledge and skill about technology and students' time management. Moreover, it also gave chance for the students to work based on the students' pace, learn anytime and anywhere (supports life-long learning), become active students, know their own progress, evaluate their own skills, discuss everything they do not understand, and encourage them being autonomous learner.

\subsection{Problem of reflective journals}

There are some negative impressions toward reflective journal from students' viewpoints including in the case of socially isolated, waste time, difficult and make frustrated. In addition, the negative impressions are getting little knowledge form reflective journal, having no experience in writing reflective journal before, understanding the material hardly, getting responds from students and teacher slowly, following the instruction hardly and plagiarizing, feeling ashame and afraid in making mistakes, and lacking motivation.

\subsection{Suggestion of reflective journal}

All the students give some suggestions regarding the implementation of Reflective journal in EFL writing class such as using e-journal learning like: penzu, daylio, daily life, presently, penCake, memorize, etc; these are to help students to enjoy writing their reflective journal, providing training or workshop for teacher and students, solving technical problem, giving reward for active and creative students, providing good facility for language, and penalizing students who conduct plagiarism

\section{Conclusion}

This project aims to find out the potentials of writing reflective learning journals as self-assessment in writing class from students' point of view. It examines students' perception of how writing reflective journals may have aided writing skills and beyond. In spite of the fact that the research data being analyzed are based one third of the students who registered for this module, interesting results are yielded. The majority of students confirm that writing reflective learning journals did change the way they look at writing skills and consequently helped them to promote their writings. Due to the scope of this study, no comprehensive details are available with regard to how their views of promoting students' writing skills may have changed. 
Even so, incorporating reflective journals still proves to be a very positive way of helping students to improve their writing. As mentioned at the beginning of this paper, reflective journals are traditionally associated with practice-based disciplines only. In the present study, it is demonstrated that the educational value of reflective journals can be applied and extended successfully to a theory-based module. This may have potential implications in the wider higher education community, especially in subject areas that are not traditionally practice or work-oriented.

A somewhat unexpected finding of this project is that most students seem to think that reflective journals are guidelines, methods, or techniques that can help them to solve writing problems. This may be a good direction for future researchers to work on. In other words, it is very interesting to find out how and to what extent teacher's feedbacks may have an effect on students' view of reflective journal. In terms of good practice regarding reflective journals, it is recommended that students should be encouraged to make connections equally between theories, and between theory and practice. After all, a good reflective journal can be theoretical discussion of two theories and the connection between theory and practice or a combination of both.

\section{References}

Bower, L. (2003). Student Reflection and Critical Thinking: A Rhetorical Analysis of 88 Portfolio Cover Letters. Journal of Basic Writing, 22( 2). 47- 59

Conway, G. (1994). Portfolio Cover Letters, Students' Self-Presentation, and Teachers' Ethics. New Directions in Portfolio Assessment: Reflective Practice, Critical Theory, and Large-Scale Scoring. Ed. Laurel Black, et al. Portsmouth, NYH: Boynton/Cook. 83-92.

Golombek, P. (2009). Second language teacher education. In A. Burns \& J. C. Richards (Eds.), The Cambridge Guide to Second Language Teacher Education (pp. 155-162). New York: Cambridge University Press.

Gorra, A., Sheridan-Ross, J., \& Phyo, K. (2008) 'Synoptic learning and assessment: case studies and experiences', Proceedings of the 9th Annual HE Academy ICS conference, Liverpool Hope University, 26th-28th August 2008

Kelly, D. (2005). A Handbook for Translator Trainers. Manchester: St. Jerome Bulpitt,

Kolb, D. (1985). Experiential Learning: Experience as the Source of Learning and Development. Englewood Cliff, N.J.: Prentice Hall

Moon, J. (1999) Learning Journals: A Handbook for Academics, Students and Professional Development, London: Kogan Page

Murcia, C. M. (2000). Teaching English as A Second or Foreign Language. $3^{\text {rd }}$ ed. TESL-EJ: The Electronic Journal for English as a Second Language

Nanay, B. (2013). Between Perception and Action. Oxford: Oxford University Press. https://doi.org/10.1093/acprof:oso/9780199695379.001.0001

O’Malley, J \& Pierce, L. (1996). Authentic Assessment for English Language Learners: Practical Approach for Teachers. New York: Addison-Wesley.

Schraw, G., \& Olafson, L. (2015). Assessing Students' Beliefs: Challenges and Solutions. In H. Fives \& M. Gill (Eds.), International Handbook of Research on 
Students' Beliefs (pp. 87-105). New York: Routledge.

Skott, J. (2015). The Promises, Problems, and Prospect of Research on Students' Beliefs. In H. Fives \& M. Gill (Eds.), International Handbook of Research on Students' Beliefs (pp. 13-30). New York: Routledge.

Smith, J., \& Yancey, K.B. (2000). Self-Assessment and Development in Writing : A collaborative Inquiry. Hampton Press. Cresskill, United States.

Sommers, J. (2011). Reflection Revisited: The Class Collage. Journal of Basic Writing, 30(1), 99-129 